\title{
Short communication: Formation of oxidized flavor compounds in concentrated milk and distillate during milk concentration
}

\author{
Y. H. Li ${ }^{* 1}$ and W. J. Wang† \\ ${ }^{*}$ College of Food Science and Biotechnology Engineering, Zhejiang Gongshang University, Hangzhou 310018, China \\ †Yangshengtang Health Products Co. Ltd., Hangzhou 311106, China
}

\begin{abstract}
Oxidized flavor stability of milk is highly associated with consumer acceptance. This study characterized oxidized flavor stability as affected by milk concentration. The selected volatiles in raw milk (RM), heated milk (HM), concentrated milk, and distillate were investigated using solid-phase microextraction-gas chromatography-mass spectrometry. Concentrated milk and distillate showed higher levels of heptanal (14.52$17.24 \mu \mathrm{g} / \mathrm{kg})$, nonanal $(5.08-8.64 \mu \mathrm{g} / \mathrm{kg}), 2$-heptanone $(25.22-73.25 \mu \mathrm{g} / \mathrm{kg})$, and 2-nonanone (10.83-17.28 $\mu \mathrm{g} /$ $\mathrm{kg}$ ) compared with RM and HM. Based on the odor activity values of different volatiles, oxidized volatiles may contribute to fatty, greasy, soapy, and dyestuff oxidized odors in concentrated milk. Oxidized volatiles of nonanal, 2-heptanone, and 2-nonanone were found to be higher in concentrated milk at $50^{\circ} \mathrm{C}$ than at $40^{\circ} \mathrm{C}$. In addition, 18 and 24 volatiles were found in unconcentrated milk and distillate, respectively. Straight aldehydes and methyl ketones showed much higher levels in distillate than in RM and HM, which also had higher levels compared with their corresponding concentrated milk samples. These results indicated that oxidized volatiles were mainly evaporated into distillate as flavor loss. They also suggested that lipid oxidation could continue drastically even under the concentration processing at a low temperature and reduced pressure.
\end{abstract} Key words: oxidized flavor, concentrated milk, distillate

\section{Short Communication}

The flavor quality of dairy products is highly associated with consumer acceptance. Oxidized flavor is a common off-flavor in milk and is described as tasting metallic, soapy, papery, fatty, mushroom, and fishy in dairy products (Hedegaard et al., 2006; Lloyd et al.,

Received June 15, 2016.

Accepted September 3, 2016.

${ }^{1}$ Correspondening author: liyanhua607@163.com 2009a). An oxidized flavor is the most critical factor in harming flavor characteristics and restricting the shelf life of milk powder (Carunchia Whetstine and Drake, 2007; Lloyd et al., 2009a,b).

Compounds that contribute to an oxidized flavor include aldehydes, ketones, and lactones, which form via lipid oxidation (Nielsena et al., 1997; Cadwallader and Singh, 2009). Oxidized flavor in dairy products could be caused by factors including initial milk quality, processing variables, oxygen exposure, light exposure, and storage conditions (Baldwin et al., 1991; Stapelfeldt et al., 1997; Carunchia Whetstine and Drake, 2007; Lloyd et al., 2009b). Previous studies on oxidized flavor in milk mainly focused on preheating treatments of milk and the storage of dairy products (Vazquez-Landaverde et al., 2005; Carunchia Whetstine and Drake, 2007; Lloyd et al., 2009a,b). Meanwhile, the parameters of concentration ratio, premature crystallization of lactose, viscosity, and denaturation of protein were the primary concern in the concentration processing.

Few studies have analyzed the flavor components in concentrated milk. Shimoda et al. (2001) indicated that volatile compounds, such as fatty acids, lactones, ketones, alkanes, alcohols, and aldehydes, are the main flavor compounds identified in commercial sweetened condensed milk by using steam distillation-gas chromatography-mass spectrometry. Patel et al. (1962) reported that a rubber smell occurred in pasteurized condensed milk during storage, which was attributed to ketones, sulfides, and fatty acid esters. Arnold and Lindsay (1969) found that methyl ketone $\left(\mathrm{C}_{3}-\mathrm{C}_{11}\right)$ and $O$-aminoacetophenone appeared to increase during storage at $27^{\circ} \mathrm{C}$ for $26 \mathrm{wk}$, and they also indicated that $O$-aminoacetophenone was the main flavor substance associated with a stale smell.

The application of reduced pressure and heating is widely used to produce concentrated milk. Milk is very susceptible to oxidation due to thermal degradation reactions. However, the effect of concentration processing on the development of oxidized flavor in concentrated milk has been ignored, although the processing is an indispensable step in the manufacture of condensed milk, 
evaporated milk, and milk powder. Moreover, the distillate derived from milk evaporation is discarded directly or used as the heat source for additional concentration processing. So far, the distillate from concentration processing has never been examined. This study investigated oxidized flavor compounds in concentrated milk and changes of volatiles in the distillate during milk concentration. The results could have important theoretical and practical implications in the flavor stability of dairy products.

Raw milk (RM) was obtained from a local dairy plant (Xingfu Farm), and $0.02 \%$ (wt/vol) $\mathrm{NaN}_{3}$ was added to it to prevent bacterial growth. The milk was stored at 4 to $6^{\circ} \mathrm{C}$. According to the methods of Lee and Sherbin (2002) and Li et al. (2013), heated milk (HM) was prepared by heating to $90^{\circ} \mathrm{C}$ for $30 \mathrm{~s}$. The milk was cooled to ambient temperature $\left(20 \pm 1^{\circ} \mathrm{C}\right)$ in a stirred water bath at 0 to $4^{\circ} \mathrm{C}$. According to the methods of Drohan et al. (1997) and Li et al. (2013), RM and HM were concentrated using laboratory-scale evaporators (N-1000, Eyela, Tokyo, Japan). The RM and HM samples were concentrated under $0.1 \mathrm{MPa} 4$ times at $40^{\circ} \mathrm{C}$ and 3 times at $50^{\circ} \mathrm{C}$, respectively. The distillate generated from concentration process was collected for the determination of oxidized flavor compounds.

Milk fat was determined by the Rose-Gottlieb method and total protein by the Kjeldahl technique with a factor of 6.38 as described by Guinee et al. (2000). Total solids in milk samples were calculated according to the weight loss by drying the samples at $105 \pm 1{ }^{\circ} \mathrm{C}$ (Almeida et al., 2009).

The volatiles were determined according to previous methods (Li et al., 2013). Duplicate analyses for GC-MS are expressed as mean values, and analyses replicated 3 times are expressed as mean $\pm \mathrm{SD}$. The odor activity value (OAV) of different volatile compounds was calculated as the ratio of the concentration and corresponding flavor threshold value. A compound could contribute to flavor when its OAV was above 1.0, and could smell slightly when its OAV ranged from 0.5 to 1.0 (Qian and Reineccius, 2003). Analysis of variance was used to distinguish the difference of the treatments, and principal component analysis (PCA) was used for the difference in volatiles of distillate were carried out using PASWStatistics18.0 Software (SPSS Inc., Chicago, IL).

The average proportions of protein and fat in all the milk samples were $3.2 \pm 0.1 \%$ and $3.2 \pm 0.2 \%$, respectively. Total milk solids were $12.1 \pm 0.3 \%$. No differences were found in the compositions of RM, HM, and reconstituted concentrated milk $(P>0.05)$.

Oxidized volatiles detected in the unconcentrated milk, concentrated milk, and distillate mainly included straight-chain aldehydes, methyl ketones, ketenes, and olefinic aldehydes. These compounds have been previously documented in different milk products and could cause different oxidized flavors (Carunchia Whetstine and Drake, 2007; Lloyd et al., 2009a; Li et al., 2013). Heptanal, nonanal, 2-heptanone, and 2-nonanone were listed as typical volatiles in discussions of oxidized flavors among products after the processes of heating and concentration, which were responsible for fatty, greasy, soapy, and dyestuff oxidized odors in dairy products, respectively.

Table 1 shows the contents of the volatile compounds in unconcentrated milk (RM and HM) and in concentrated milk (RMC and HMC). Low levels of oxidized volatiles were found in liquid milk (RM and HM). The concentrations of heptanal, nonanal, 2-heptanone, and 2 -nonanone were $1.92,1.02,5.44$, and $1.73 \mu \mathrm{g} / \mathrm{kg}$ in RM, and $2.32,1.24,7.22$, and $2.11 \mu \mathrm{g} / \mathrm{kg}$ in HM, respectively. Based on the flavor thresholds of these volatiles of 3.0, $1.0,5.0$, and $5.0 \mu \mathrm{g} / \mathrm{kg}$ in milk (Bendall, 2001; VazquezLandaverde et al., 2005), the corresponding OAV of these compounds were $0.64,1.02,1.09$, and 0.35 in $\mathrm{RM}$, and $0.77,1.24,1.44$, and 0.42 in HM, respectively. These compounds did not differ significantly between HM and RM $(P>0.05)$. The OAV results indicated that volatiles of nonanal and 2-heptanone contributed to off-flavors and could endow RM and HM samples with fatty and soapy odors associated with oxidized flavor. Heptanal could be detected and contributed to the oxidized flavor of HM $(0.5<\mathrm{OAV}<1.0)$.

Oxidized volatiles in concentrated milk occurred at higher levels than in the corresponding unconcentrated groups: heptanal $(14.52-17.24 \mu \mathrm{g} / \mathrm{kg})$, nonanal (5.08-8.64 $\mu \mathrm{g} / \mathrm{kg})$, 2-heptanone $(25.22-73.25 \mu \mathrm{g} / \mathrm{kg})$, and 2-nonanone $(10.83-17.28 \mu \mathrm{g} / \mathrm{kg})$. The $\mathrm{OAV}$ of these volatiles in concentrated milk were from 4.84 to 5.75, from 5.08 to 8.64 , from 5.04 to 14.65 , and from 2.17 to 3.46 , respectively. Compared with RM and HM, the concentration treatment increased the formation of oxidized flavor significantly $(P<0.05)$. Meanwhile, the oxidized volatiles nonanal, 2-heptanone, and 2-nonanone in concentrated milk (except 2-nonanone in RMC) processed at $50^{\circ} \mathrm{C}$ had higher levels than milk processed at $40^{\circ} \mathrm{C}$. This result also suggested that lipid oxidation continued under the concentration conditions (i.e., low temperature and reduced pressure).

Table 2 shows the volatiles of RM, HM, and their corresponding distillates during concentration. A total of 18 and 24 volatiles were found in unconcentrated milk and distillate, respectively. Among them, straight aldehydes and methyl ketones occurred at much higher levels in distillate than in RM and HM, which also had higher levels compared with the corresponding concentrated milk samples (Table 1). Alkanes were slightly increased because of the oxidation (Nursten, 1997); 
Table 1. Contents of volatile compounds in different concentrated milks

\begin{tabular}{|c|c|c|c|c|}
\hline \multirow[b]{2}{*}{ Treatment $^{1}$} & \multicolumn{4}{|c|}{ Contents of volatile compounds $(\mu \mathrm{g} / \mathrm{kg}$ ) } \\
\hline & Heptanal & Nonanal & 2-Heptanone & 2-Nonanone \\
\hline $\mathrm{RM}$ & $1.92 \pm 0.27^{\mathrm{a}}$ & $1.02 \pm 0.15^{\mathrm{a}}$ & $5.44 \pm 0.78^{\mathrm{a}}$ & $1.73 \pm 0.17^{\mathrm{a}}$ \\
\hline HM & $2.32 \pm 0.32^{\mathrm{a}}$ & $1.24 \pm 0.18^{\mathrm{a}}$ & $7.22 \pm 0.87^{\mathrm{ab}}$ & $2.11 \pm 0.30^{\mathrm{a}}$ \\
\hline RMC40 & $14.52 \pm 1.55^{\mathrm{b}}$ & $5.08 \pm 0.52^{\mathrm{b}}$ & $25.22 \pm 3.41^{\mathrm{b}}$ & $10.83 \pm 1.30^{\mathrm{b}}$ \\
\hline RMC50 & $16.40 \pm 1.49^{\mathrm{b}}$ & $7.56 \pm 0.69^{\mathrm{cd}}$ & $46.37 \pm 5.34^{\mathrm{c}}$ & $14.18 \pm 1.68^{\mathrm{bc}}$ \\
\hline HMC40 & $14.13 \pm 1.43^{\mathrm{b}}$ & $6.23 \pm 0.78^{\mathrm{bc}}$ & $45.27 \pm 6.07^{\mathrm{c}}$ & $13.13 \pm 1.42^{\mathrm{bc}}$ \\
\hline HMC50 & $17.24 \pm 1.56^{\mathrm{b}}$ & $8.64 \pm 0.83^{\mathrm{d}}$ & $73.25 \pm 8.25^{\mathrm{d}}$ & $17.28 \pm 1.58^{\mathrm{d}}$ \\
\hline
\end{tabular}

$\overline{\mathrm{a}-\mathrm{d}}$ Means in each column with different letters were significantly different among the treatments in liquid milk and concentrated milk $(P<0.05)$.

${ }^{1} \mathrm{RM}=$ raw milk; $\mathrm{HM}=$ heated milk; RMC and $\mathrm{HMC}=$ the corresponding concentrated milks of $\mathrm{RM}$ and $\mathrm{HM}$ processed at 40 or $50^{\circ} \mathrm{C}$.

however, the levels of toluene, ethylbenzene, $p$-xylene, D-limonene, naphthalene, and ethyl caprylate showed the opposite tendency. These compounds were probably transferred from forages (Contarini et al., 1997; Garde et al., 2005), and some amount of them evaporated into the distillate. 2-Pentyl-furan, 3-octen-2-one, 3,5-octadien-2-one, 2-nonenal, benzothiazole, and 2-decenal were only detected in the distillate and not in liquid milk (RM and HM).

Figure 1 shows the biplot of the PCA for the typical volatiles in distillate as well as in RM and HM. Thir- teen volatiles were selected as the test set. By reducing the dimensionality of these volatiles, liquid milk and distillate could be clearly distinguished by principal components (PC)1 (77.37\%) and PC2 (15.39\%). The cumulative extraction sum of the $2 \mathrm{PC}$ was $92.76 \%$, and the initial eigenvalue was $>1$. In addition, the differences were clear among the distillate samples. The distillate from the lower intensity concentration process $\left(40^{\circ} \mathrm{C}, 4\right.$ times) had a high PC1 for both RM and HM. In our preliminary experiments, the concentration process was performed 3 and 4 times at $40^{\circ} \mathrm{C}$ and $50^{\circ} \mathrm{C}$,

Table 2. Volatiles in liquid milk and distillate $(\mu \mathrm{g} / \mathrm{kg})^{1}$

\begin{tabular}{|c|c|c|c|c|c|c|c|}
\hline \multirow[b]{2}{*}{ Volatile } & \multirow{2}{*}{$\begin{array}{c}\mathrm{RT} \\
(\mathrm{min})\end{array}$} & \multicolumn{2}{|c|}{ Liquid milk } & \multicolumn{4}{|c|}{ Distillate $^{2}$} \\
\hline & & $\mathrm{RM}$ & $\mathrm{HM}$ & D-RMC 40 & D-RMC 50 & D-HMC 40 & D-HMC 50 \\
\hline Toluene & 12.59 & $30.78^{\mathrm{b}}$ & $30.06^{\mathrm{b}}$ & $18.83^{\mathrm{a}}$ & $15.23^{\mathrm{a}}$ & $18.33^{\mathrm{a}}$ & $16.47^{\mathrm{a}}$ \\
\hline Hexanal & 14.33 & $3.03^{\mathrm{a}}$ & $3.37^{\mathrm{a}}$ & $59.78^{\mathrm{bc}}$ & $37.78^{\mathrm{b}}$ & $84.01^{\mathrm{d}}$ & $79.12^{\mathrm{cd}}$ \\
\hline Ethylbenzene & 17.64 & $5.40^{\mathrm{b}}$ & $5.24^{\mathrm{b}}$ & $3.41^{\mathrm{a}}$ & $3.37^{\mathrm{a}}$ & $3.49^{\mathrm{a}}$ & $3.41^{\mathrm{a}}$ \\
\hline$p$-Xylene & 18.07 & $12.38^{\mathrm{b}}$ & $12.83^{\mathrm{b}}$ & $7.56^{\mathrm{a}}$ & $6.76^{\mathrm{a}}$ & $7.55^{\mathrm{a}}$ & $6.80^{\mathrm{a}}$ \\
\hline 2-Heptanone & 19.14 & $5.44^{\mathrm{a}}$ & $7.22^{\mathrm{a}}$ & $90.40^{\mathrm{b}}$ & $71.27^{\mathrm{b}}$ & $94.90^{\mathrm{b}}$ & $81.82^{\mathrm{b}}$ \\
\hline Heptanal & 19.66 & $1.92^{\mathrm{a}}$ & $2.32^{\mathrm{a}}$ & $47.87^{\mathrm{bc}}$ & $33.18^{\mathrm{b}}$ & $59.22^{\mathrm{c}}$ & $57.96^{\mathrm{c}}$ \\
\hline 2-Pentyl-furan & 24.10 & $\mathrm{ND}^{3}$ & ND & $4.48^{\mathrm{a}}$ & $5.36^{\mathrm{a}}$ & $4.60^{\mathrm{a}}$ & $5.36^{\mathrm{a}}$ \\
\hline Octanal & 24.50 & $0.71^{\mathrm{a}}$ & $0.64^{\mathrm{a}}$ & $13.73^{\mathrm{bc}}$ & $10.89^{\mathrm{b}}$ & $21.45^{\mathrm{c}}$ & $17.22^{\mathrm{bc}}$ \\
\hline D-Limonene & 25.82 & $5.66^{\mathrm{c}}$ & $5.56^{\mathrm{bc}}$ & $4.01^{\mathrm{ab}}$ & $3.01^{\mathrm{a}}$ & $4.40^{\mathrm{abc}}$ & $3.23^{\mathrm{a}}$ \\
\hline 3-Octen-2-one & 26.14 & ND & ND & $7.06^{\mathrm{a}}$ & $6.38^{\mathrm{a}}$ & $7.41^{\mathrm{a}}$ & $6.59^{\mathrm{a}}$ \\
\hline 3,5-Octadien-2-one & 27.47 & ND & ND & $4.06^{\mathrm{a}}$ & $3.71^{\mathrm{a}}$ & $4.44^{\mathrm{a}}$ & $4.25^{\mathrm{a}}$ \\
\hline 2-Nonanone & 28.38 & $1.73^{\mathrm{a}}$ & $2.11^{\mathrm{a}}$ & $35.29^{\mathrm{bc}}$ & $19.90^{\mathrm{ab}}$ & $53.33^{\mathrm{c}}$ & $39.16^{\mathrm{c}}$ \\
\hline Nonanal & 28.89 & $1.02^{\mathrm{a}}$ & $1.24^{\mathrm{a}}$ & $8.15^{\mathrm{bc}}$ & $5.39^{\mathrm{b}}$ & $11.09^{\mathrm{c}}$ & $8.10^{\mathrm{bc}}$ \\
\hline 2-Nonenal & 31.07 & ND & ND & $4.29^{\mathrm{a}}$ & $3.92^{\mathrm{a}}$ & $4.33^{\mathrm{a}}$ & $3.80^{\mathrm{a}}$ \\
\hline Octanoic acid & 31.62 & $5.11^{\mathrm{a}}$ & $4.91^{\mathrm{a}}$ & $4.61^{\mathrm{a}}$ & $4.11^{\mathrm{a}}$ & $5.33^{\mathrm{a}}$ & $4.55^{\mathrm{a}}$ \\
\hline Naphthalene & 32.29 & $7.09^{\mathrm{b}}$ & $7.25^{\mathrm{b}}$ & $5.40^{\mathrm{ab}}$ & $4.57^{\mathrm{a}}$ & $5.53^{\mathrm{ab}}$ & $4.64^{\mathrm{a}}$ \\
\hline Ethyl caprylate & 32.40 & $3.83^{\mathrm{b}}$ & $3.48^{\mathrm{ab}}$ & $2.56^{\mathrm{ab}}$ & $2.19^{\mathrm{a}}$ & $2.73^{\mathrm{ab}}$ & $2.33^{\mathrm{a}}$ \\
\hline Dodecane & 32.63 & $2.39^{\mathrm{a}}$ & $2.55^{\mathrm{ab}}$ & $4.61^{\mathrm{c}}$ & $4.31^{\mathrm{bc}}$ & $4.51^{\mathrm{c}}$ & $4.39^{\mathrm{c}}$ \\
\hline Benzothiazole & 33.87 & ND & ND & $3.41^{\mathrm{a}}$ & $3.01^{\mathrm{a}}$ & $2.71^{\mathrm{a}}$ & $3.03^{\mathrm{a}}$ \\
\hline 2-Decenal & 34.89 & ND & ND & $1.86^{\mathrm{a}}$ & $1.65^{\mathrm{a}}$ & $2.28^{\mathrm{a}}$ & $1.81^{\mathrm{a}}$ \\
\hline 2-Undecanone & 36.00 & $2.57^{\mathrm{a}}$ & $2.63^{\mathrm{a}}$ & $15.22^{\mathrm{bc}}$ & $11.43^{\mathrm{b}}$ & $16.01^{\mathrm{c}}$ & $12.19^{\mathrm{bc}}$ \\
\hline Tridecane & 36.17 & $1.35^{\mathrm{a}}$ & $1.47^{\mathrm{a}}$ & $1.60^{\mathrm{a}}$ & $1.43^{\mathrm{a}}$ & $1.71^{\mathrm{a}}$ & $1.36^{\mathrm{a}}$ \\
\hline Decanoic acid & 37.71 & $8.73^{\mathrm{a}}$ & $8.73^{\mathrm{a}}$ & $8.01^{\mathrm{a}}$ & $6.54^{\mathrm{a}}$ & $8.30^{\mathrm{a}}$ & $6.57^{\mathrm{a}}$ \\
\hline Tetradecane & 38.42 & $3.35^{\mathrm{a}}$ & $3.62^{\mathrm{a}}$ & $4.55^{\mathrm{a}}$ & $4.41^{\mathrm{a}}$ & $4.70^{\mathrm{a}}$ & $4.50^{\mathrm{a}}$ \\
\hline
\end{tabular}

${ }^{\mathrm{a}-\mathrm{d}}$ Means in each row with different letters indicate significant differences among the treatments in liquid milk and distillate $(P<0.05)$.

${ }^{1} \mathrm{RT}=$ retention time; $\mathrm{RM}=$ raw milk; HM = heated milk; D-RMC and D-HMC = the distillates of concentrated RM and HM.

${ }^{2}$ The subscripted values indicate the temperature $\left(40\right.$ or $\left.50^{\circ} \mathrm{C}\right)$ at which the samples were processed.

${ }^{3}$ Not detected. 


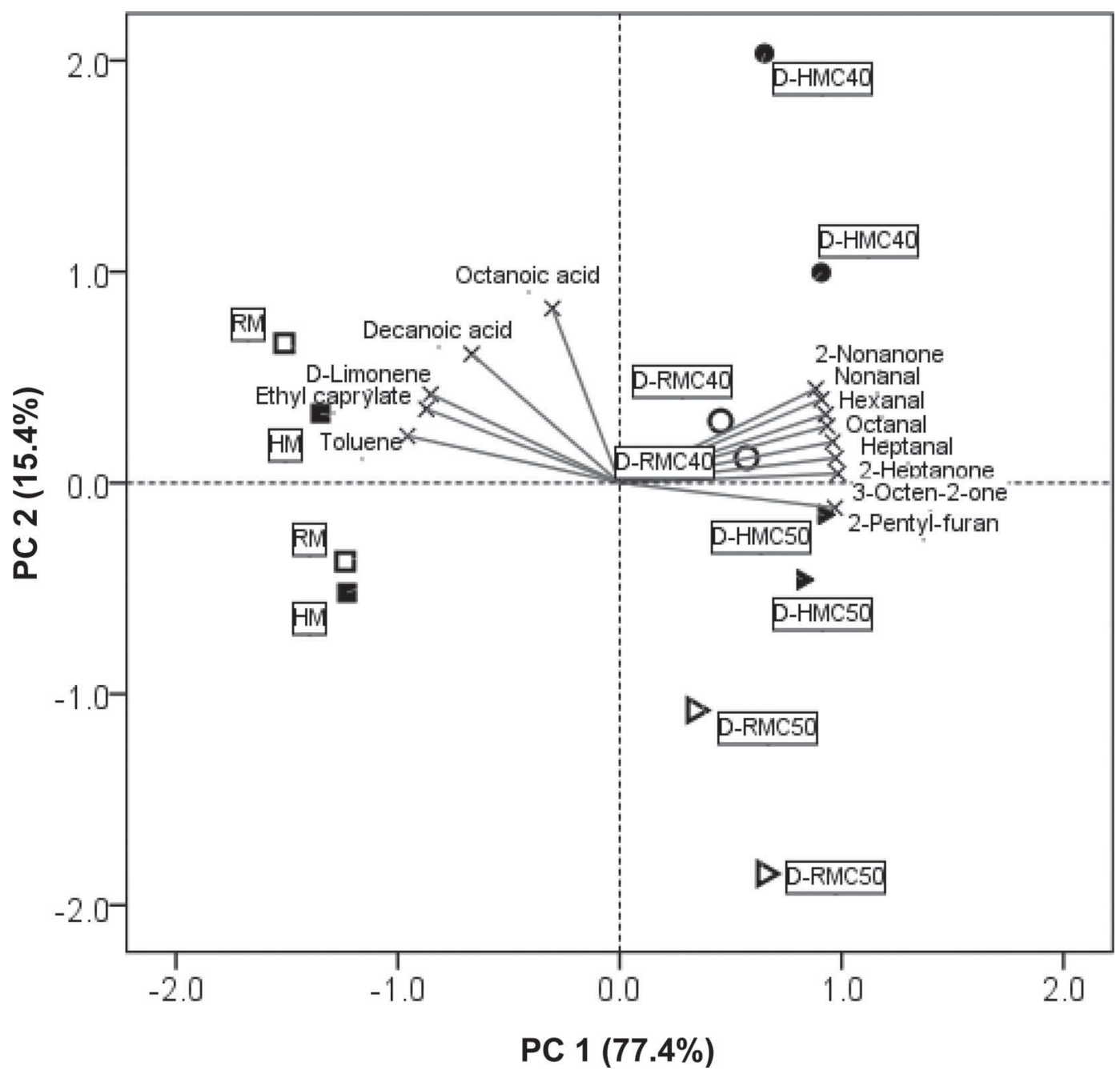

Figure 1. The biplot of principal component $(\mathrm{PC})$ analysis on the volatiles in distillate. $\mathrm{RM}=$ raw milk; HM = heated milk; D-RMC and $\mathrm{D}-\mathrm{HMC}=$ the distillates of concentrated RM and $\mathrm{HM}$ (40 and 50 indicate the temperature, 40 or $50^{\circ} \mathrm{C}$, at which the samples were processed).

respectively. We found that the intensity of the concentration process became progressively lower with the following temperatures and repetitions: $50^{\circ} \mathrm{C}, 3$ times; $50^{\circ} \mathrm{C}, 4$ times; $40^{\circ} \mathrm{C}, 3$ times; and $40^{\circ} \mathrm{C}, 4$ times. The temperature parameter of the concentration process is actually of little significance and not a critical part of the process. Based on this intensity, both RM and HM were processed 4 times at $40^{\circ} \mathrm{C}$ and 3 times at $50^{\circ} \mathrm{C}$ to investigate significant differences among those processes for concentration.

Furthermore, the distillate from HM had a higher value of $\mathrm{PC} 1$ than that of $\mathrm{RM}$ under the same intensity of concentration. Principal component 1 allowed the linear combination of aldehydes, ketones, and 2-pentylfuran and showed that they were positively correlated, with values ranging from 0.884 to 0.973 . Principal component 2 allowed the different groups of distillate to be distinguished. Preheating could increase the formation of aldehydes, ketones, and 2-pentyl-furan. Other volatiles also showed higher levels in the distillate derived from processing at $40^{\circ} \mathrm{C}$ compared with $50^{\circ} \mathrm{C}$.

Among the components affecting flavor in distillate, straight aldehydes and methyl ketones were the critical contributors of oxidized flavor properties. 2-Pentylfuran and benzothiazole originate from lactose and phenylalanine through the Maillard reaction, respectively, and strongly contribute to caramel and rusty off-flavors (Nursten, 1997). 3-Octen-2-one and 3,5-octadien-2-one generated by oxidation of linoleic acid and arachidonic acid, respectively, can contribute a mushroom odor. 2-Nonenal and 2-decenal formed from oleic acid can contribute cardboard and fatty odors, respectively (Day and Lillard, 1960; Ullrich and Grosch, 1987; Lloyd et al., 2009a).

The results of this study indicate that oxidized volatiles detected in RM, HM, concentrated milk, and 
distillate include mainly straight-chain aldehydes and ketones. Compared with RM and HM, oxidized volatiles are significantly increased in concentrated milk. The heat treatment could increase the oxidized volatiles in concentrated milk. Levels of straight aldehydes and methyl ketones in distillate were sharply increased compared with their corresponding concentrated milk samples. Lipid oxidation is suggested to continue drastically under the concentration process controlling with low temperature and reduced pressure.

\section{ACKNOWLEDGMENTS}

The authors acknowledge financial support from the National Natural Science Foundation of the People's Republic of China (Project Number 31401557) and the Natural Science Foundation of Zhejiang Province (Project Number LY17C200005).

\section{REFERENCES}

Almeida, K. E., A. Y. Tamime, and M. N. Oliveira. 2009. Influence of total solids contents of milk whey on the acidifying profile and viability of various lactic acid bacteria. LWT Food Sci. Technol. 42:672-678.

Arnold, R. G., and R. C. Lindsay. 1969. Quantitative determination of $\mathrm{N}$-methyl ketones and O-aminoacetophenone in sterilized concentrated milk. J. Dairy Sci. 52:1097-1100.

Baldwin, A. J., H. R. Cooper, and K. C. Palmer. 1991. Effect of preheat treatment and storage on the properties of whole milk powder-changes in sensory properties. Neth. Milk Dairy J. 45:97-116.

Bendall, J. G. 2001. Aroma compounds of fresh milk from New Zealand cows fed different diets. J. Agric. Food Chem. 49:4825-4832.

Cadwallader, K. R., and T. K. Singh. 2009. Flavours and off-flavours in milk and dairy products. Pages $633-635$ in Advanced Dairy Chemistry. P. L. H. McSweeney and P. F. Fox, ed. Springer Science and Business Media, LLC, New York, NY.

Carunchia Whetstine, M. E., and M. A. Drake. 2007. The flavor and flavor stability of skim and whole milk powders. Pages $217-251$ in Flavor of Dairy Products. K. R. Cadwallader, M. A. Drake, and R. McGorrin, ed. ACS Publishing, Washington, DC.

Contarini, G., M. Povolo, R. Leardi, and T. M. Piero. 1997. Influence of heat treatment on the volatile compounds of milk. J. Agric. Food Chem. 45:3171-3177.

Day, E. A., and D. A. Lillard. 1960. Autoxidation of milk lipids. I. Identification of volatile monocarbonyl compounds from autoxidized milk fat. J. Dairy Sci. 43:585-597.
Drohan, D. D., A. Tziboula, D. McNulty, and D. S. Horne. 1997. Milk protein-carrageenan interactions. Food Hydrocoll. 11:101-107.

Garde, S., M. Avila, M. Medina, and M. Nunez. 2005. Influence of a bacteriocin-producing lactic culture on the volatile compounds, odour and aroma of Hispanico cheese. Int. Dairy J. 15:1034-1043.

Guinee, T. P., M. A. E. Auty, and M. A. Fenelon. 2000. The effect of fat content on the rheology, microstructure and heat-induced functional characteristics of Cheddar cheese. Int. Dairy J. 10:277-288.

Hedegaard, R. V., D. Kristensen, J. H. Nielsen, M. B. Frost, H. Ostdal, J. E. Hermansen, M. Kroger-Ohlsen, and L. H. Skibsted. 2006. Comparison of descriptive sensory analysis and chemical analysis for oxidative changes in milk. J. Dairy Sci. 89:495-504.

Lee, S. J. E., and J. W. Sherbin. 2002. Chemical changes in bovine milk fat globule membrane caused by heat treatment and homogenization of whole milk. J. Dairy Res. 69:555-567.

Li, Y. H., L. W. Zhang, W. J. Wang, and X. Han. 2013. Differences in particle characteristics and oxidized flavor as affected by heatrelated processes of milk powder. J. Dairy Sci. 96:4784-4793.

Lloyd, M. A., M. A. Drake, and P. D. Gerard. 2009a. Flavor variability and flavor stability of U.S.-produced whole milk powder. J. Food Sci. 74:S334-S343.

Lloyd, M. A., S. J. Hess, and M. A. Drake. 2009b. Effect of nitrogen flushing and storage temperature on flavor and shelf-life of whole milk powder. J. Dairy Sci. 92:2409-2422.

Nielsena, B. R., H. Stapelfeldta, and L. H. Skibsted. 1997. Early prediction of the shelf-life of medium-heat whole milk powders using stepwise multiple regression and principal component analysis. Int. Dairy J. 7:341-348.

Nursten, H. E. 1997. The flavour of milk and dairy products: I. Milk of different kinds, milk powder, butter and cream. Int. J. Dairy Technol. 50:48-56.

Patel, T. D., H. E. Calbert, D. G. Morgan, and F. M. Strong. 1962. Changes in the volatile flavor components of sterilized concentrated milk during storage. J. Dairy Sci. 45:601-606.

Qian, M., and G. A. Reineccius. 2003. Quantification of aroma compounds in Parmigiano Reggiano cheese by a dynamic headspace gas chromatography-mass spectrometry technique and calculation of odor activity value. J. Dairy Sci. 86:770-776.

Shimoda, M., Y. Yoshimura, T. Yoshimura, K. Noda, and Y. Osajima. 2001. Volatile flavor compounds of sweetened condensed milk. J. Food Sci. 66:804-807.

Stapelfeldt, H., B. R. Nielsen, and L. H. Skibsted. 1997. Effect of heat treatment, water activity and storage temperature on the oxidative stability of whole milk powder. Int. Dairy J. 7:331-339.

Ullrich, F., and W. Grosch. 1987. Identification of the most intense volatile flavour compounds formed during autoxidation of linoleic acid. Z. Lebensm. Unters. Forsch. 184:277-282.

Vazquez-Landaverde, P. A., G. Velazquez, J. A. Torres, and M. C. Qian. 2005. Quantitative determination of thermally derived offflavor compounds in milk using solid-phase microextraction and gas chromatography. J. Dairy Sci. 88:3764-3772. 